\title{
The Effect of Disease Duration on Foot Plantar Pressure Values in Patients with Type 2 Diabetes Mellitus
} Tip 2 Diabetes Mellituslu Hastalarda Ayak Taban Basıncına Hastalık Süresinin Etkisi

\author{
Hakan TUNA ${ }^{1}$, Murat BIRTANE ${ }^{1}$, Sibel GÜLDIKEN² ${ }^{2}$ Neslihan Atile SOYSAL ${ }^{2}$, Özgür TAŞPINAR ${ }^{1}$, Necdet SÜT ${ }^{3}$, Nurettin TAŞTEKIN ${ }^{1}$ \\ ${ }^{1}$ Department of Physical Medicine and Rehabilitation, Trakya University, Edirne, Turkey \\ ${ }^{2}$ Department of Endocrinology, Trakya University, Edirne, Turkey \\ ${ }^{3}$ Department of Biostatistics, Trakya University, Edirne, Turkey
}

\begin{abstract}
Objective: Diabetic foot problems and consequent ulceration in older patients are a major cause of morbidity and permanent disability. One of the major risk factors for ulceration is foot pressure changes. We, in this study, aimed to identify any relation between disease duration and plantar pressure of patients with type 2 diabetes.

Material and Methods: This study was done on 168 feet of 84 diabetic patients. Demographic parameters and body mass index were noted. The patients were allocated according to disease duration as being more (Group 1) or less than 10 years (Group 2). Static and dynamic pedographic evaluation was performed for each of the patients, and results were compared between the groups.

Results: The static pedobarographic evaluation revealed significantly higher forefoot plantar force percentage values in the left feet of patients in group 1. We found that peak phalanx pressure was significantly higher in the left foot, while the contact area was lower in the right foot of group 1 patients, by dynamic pedobarographic evaluation.

Conclusion: Contact area decreases and peak pressure increases during walking in forefoot after 10 years of disease duration in type 2 diabetic patients. Key Words: Diabetic foot, plantar pressure, pedobarography, disease duration
\end{abstract}

Özet

Amaç: Diabetes mellituslu hastalarda ayak problemleri ve beraberindeki ülserasyonlar, morbidite ve kalıcı disabilitenin en önemli nedenidir. Ülserasyon için önemli risk faktörlerinden biri ayaktaki basınç değişiklikleridir. Biz bu çalışmada, tip 2 diabetli hastalarda taban basıncı ve hastalık süresi arasındaki ilişkinin varlığını tanımlamaya çalıştık.

Gereç ve Yöntemler: Bu çalışmada 84 diabetik hastanın 168 ayağı değerlendirildi. Yaş, ağırlık, boy ve vücut kitle indeksi gibi demografik özellikler kaydedildi. Hastalar 10 yıldan az (Grup 1) veya fazla (Grup 2) hastalık süresine göre ayrıldı. Statik ve dinamik pedografik değerlendirme her hastada uygulandı ve sonuçlar gruplar arasında karşılaştırıldı.

Bulgular: Statik pedobarografik değerlendirmede Grup 1'deki hastaların sol ön ayak taban basıncı ortalama değeri anlamlı yüksekti $(p<0,05)$. Biz sol ayak pik falanks basınçlarını anlamlı yüksek $(p<0,05)$ bulmamıza karşın, sağ ayak taban temas alanı dinamik pedobarografik değerlendirmede Grup 1 hastalarda anlamlı düşüktü $(p<0,05)$.

Sonuç: Taban temas alanı azalması ve yürüme sırasında ön ayak pik basıncı 10 yıldan fazla hastalık süresi olan tip 2 diabetik hastalarda artmıştır. Anahtar Kelimeler: Diabetik ayak, taban basıncı, pedobarografi, hastalık süresi

\section{Introduction}

Diabetic foot problems in old patients may lead to morbidity and longlasting disability and are also prominent leading factors of hospitalization. The percentage of diabetes is higher in the older population, and the tendency increases with ageing (1).
Increased levels of plantar pressure have been accused of playing a role in the occurrence of many structural foot abnormalities (2). Known high-risk factors for deformities are advanced age, a history of diabetes for more than 10 years, altered gait and ambulatory dysfunction, foot pressure abnormality, atrophy of soft tissue, and plantar fat pad and deformities (1). As an

Address for Correspondence / Yazışma Adresi: Hakan Tuna, MD, Department of Physical Medicine and Rehabilitation, Trakya University, Edirne, Turkey. Phone: +9028423576 41/4716 E-mail: hakantuna@trakya.edu.tr

Received/Geliş Tarihi: May/Mayıs 2013 Accepted/Kabul Tarihi: January/Ocak 2014

OTelif Hakkı 2014 Türkiye Fiziksel Tıp ve Rehabilitasyon Derneği - Makale metnine www.ftrdergisi.com web sayfasından ulaşlabilir.

OCopyright 2014 by Turkish Society of Physical Medicine and Rehabilitation - Available online at www.ftrdergisi.com 
expected result, plantar ulcers under the metatarsal heads can occur more easily in diabetes mellitus patients with peripheral neuropathy due to higher localized pressures on insensitive skin (3). It has also been shown in a study that high plantar pressure is an important etiopathogenic risk factor for the development of diabetic plantar ulcers, and ulceration is reported to be frequently responsible for lower-extremity amputation in another study $(4,5)$. Therefore, risk of skin breakdown is often investigated by peak plantar pressures, which are determinative (6).

The National Diabetes Advisory Board has suggested that $50 \%$ to $75 \%$ of all amputations could be prevented with proper assessment, patient education, and comprehensive and coordinated care. The cost of care for foot disease and ulceration is significant and much greater than preventive efforts (1). On the other hand, there is still an ongoing controversy among researchers in terms of off-loading footwear in the management of ulcers (7).

As the effect of the management is controversial, it seems to be realistic to focus on preventive measures. Peak pressure measurement studies could be performed frequently to decrease the tendency of ulceration in specific foot sites. Foot plantar pressure changes could allow the clinician to handle each patient correctly. We, in this study, aimed to clear any relation between disease duration and plantar pressure of patients with type 2 diabetes.

\section{Material and Methods}

A local ethical committee approved the methodology of the study, and informed consent was taken from all cases.

\section{Subjects}

This study was done on 168 feet of 84 diabetic patients. The patients were sent to our foot department from the Endocrinology Department of the same hospital. The study participants were excluded if they had: 1) diabetic ulceration, 2) acute lower extremity trauma, 3) lower extremity surgery, like prosthesis operations of the hip, knee, ankle, or foot, 4) leg length discrepancies, 5) problems of cooperation, including eye, ear, or cognitive disorders, 6) vascular insufficiency, and 7) walking aids. Demographic properties, like age, weight, height, and body mass index (BMI), were assessed and noted. The patients were allocated according to disease duration as being more or less than 10 years. Forty-three patients had diabetes with duration more than 10 years (Group 1 ) and 41 had less than 10 years (Group 2).

\section{Pedobarographic Evaluation}

A Mini-Emed pedobarography device was used for pedobarographic assessment (Novel, Munich, Germany). This system allows static and dynamic plantar pressure measurements. The machine consists of a Canon color printer, monitor, pressure-sensitive platform, power supply, and remote control. The dimensions of the platform are $650 \times 290 \times 25 \mathrm{~mm}$. Three sensors exist in each $\mathrm{cm}^{2}$ of the platform. Each sensor has dimensions of area of $360 \times 180 \mathrm{~mm}$. The pressure range is $2-127 \mathrm{~N} / \mathrm{cm}^{2}$, the resolution is $1 \mathrm{~N} / \mathrm{cm}^{2}$, and the accuracy related to the foot is $\pm 5 \%$ (8).
Overpressure on one side of the foot was precluded by asking questions to the patients to prevent concentration to the foot and to prevent the wrong tended posture. We asked them to look at a constant point on the wall that was $3 \mathrm{~m}$ away. The average width of stride was arranged to be $8 \mathrm{~cm}$ while standing on the platform. The data on the monitor screen were fixed and recorded as the weight on a single foot, equal to $50 \%$ of the body weight. Each foot was evaluated separately. During the static measurement, eight parameters were evaluated: 1$)$ forefoot peak pressure value $\left(\mathrm{N} / \mathrm{cm}^{2}\right), 2$ ) rear foot peak pressure value $\left.\left(\mathrm{N} / \mathrm{cm}^{2}\right), 3\right)$ total plantar force $\left.(\mathrm{N}), 4\right)$ forefoot plantar force percentage $(\%), 5)$ rear foot plantar force percentage $(\%), 6)$ total contact area $\left.\left(\mathrm{cm}^{2}\right), 7\right)$ forefoot plantar contact area percentage (\%), and 8) rear foot plantar contact area percentage (\%).

The subjects walked continuously along a $30-\mathrm{m}$-long area for a few minutes before reaching a 5-m long wooden walking platform for dynamic measurement. They were instructed to place the foot on the platform during their normal walking rhythm. The normal walking rhythm was taken as the standard walking speed that could maximally affect pressure values by as much as $7 \%(9)$.

During dynamic measurement, seven parameters were evaluated: 1) peak phalanx pressure $\left.\left(\mathrm{N} / \mathrm{cm}^{2}\right), 2\right)$ medial forefoot peak pressure $\left.\left(\mathrm{N} / \mathrm{cm}^{2}\right), 3\right)$ middle forefoot peak pressure $(\mathrm{N} /$ $\left.\mathrm{cm}^{2}\right)$, 4) lateral forefoot peak pressure $\left.\left(\mathrm{N} / \mathrm{cm}^{2}\right), 5\right)$ middle foot peak pressure $\left.\left(\mathrm{N} / \mathrm{cm}^{2}\right), 6\right)$ rear foot peak pressure $\left(\mathrm{N} / \mathrm{cm}^{2}\right)$, and 7) plantar contact area $\left(\mathrm{cm}^{2}\right)$.

\section{Statistical Analysis}

The findings of the patients with higher and lower disease duration were determined and compared by independent sample-t test or chi-square test. The static and dynamic values were compared using independent-sample t-test and MannWhitney U-test, according to normal distribution. Wilcoxon signed rank test was used to compare right-left measurements. Statistica 7.0 (StatSoft. Inc. Tulsa, OK, USA) statistical software was used for the statistical analysis.

\section{Results}

One hundred sixty-eight feet of 84 patients were investigated. Eighty-six of the feet belonged to 43 group 1 patients with higher disease duration, and the other 82 belonged to 41 group 2 patients with lower disease duration. The characteristics of the patients are summarized in Table 1. The mean age was different between the groups $(p=0.000)$, while they were comparable in terms of body mass index $(p=0.079)$. The static pedobarographic evaluation revealed significantly higher forefoot plantar force percentage values in left feet of the patients in group 1 $(p=0.032)$ (Table 2). Also, the mean rear foot plantar force percentage value was found to be significantly lower in group 1 patients $(p=0.032$ ) (Table 2). When we evaluated dynamic pedobarographic parameters, we found that peak phalanx pressure was significantly higher $(p=0.010)$, while the contact area was significantly lower in group 1 patients $(p=0.023)$ (Table 3$)$. 


\section{Discussion}

Awareness of risk factors for amputations is important both for the education of the people at high risk and for the management of modifiable factors in diabetic patients (10). In diabetes, most plantar foot ulcers occur as a result of protective sensation loss due to peripheral neuropathy and changes in foot structure, leading to increased levels of mechanical stress (11). The clinical risk factor spectrum for ulceration includes vascular and neurologic deficits and foot deformities, followed by minor trauma, repetitive trauma, skin ulceration, and faulty wound healing. Risk factors, such as limited joint mobility, hallux valgus, hammer toes, and prominent metatarsal heads, should be assessed regularly for prevention of ulcers in at-risk patients (1).

Specific high-risk areas of the foot should be given special care during risk assessment. There are many methods of plantar pressure assessment. One simple method is the evaluation of pressure by a disposable mat. More complicated methods also exist that evaluate the magnitude of loading or the depth of subcutaneous tissue under the foot (12). In this study, the main assessed causative factor was foot plantar pressure, measured by

Table 1. The characteristics of the diabetic study population

\begin{tabular}{lccc}
\hline & $\begin{array}{c}\text { Disease duration } \\
\text { more than 10 years } \\
(\text { Group 1) } \\
(\mathbf{n}=\mathbf{4 3 )}\end{array}$ & $\begin{array}{c}\text { Disease duration } \\
\text { less than 10 years } \\
(\text { Group 2) } \\
(\mathbf{n}=\mathbf{4 1})\end{array}$ & $\mathbf{p}$ \\
\hline Age (year) & $63.5(9.2)$ & $54.3(11.5)$ & 0.000 \\
Gender & 27 female, 16 male & 23 female, 18 male & 0.618 \\
Deformities & 8 hallux valgus & 6 hallux valgus & 0.798 \\
& 5 pes planus & 7 pes planus & \\
BMl $\left(\mathrm{kg} / \mathrm{m}^{2}\right)$ & $28.8(5.0)$ & $31.3(7.5)$ & 0.079 \\
\hline
\end{tabular}

Data presented are mean values (SD).

*:p 0.05

BMI: body mass index pedobarography. Neurological status of the patients was ignored, as were deformities, which are two contributing factors to ulcer occurrence.

Diabetes seemed to a pressure imbalance between the forefoot and the rear foot during walking (13-15). Mueller et al. (13) showed higher peak plantar pressure in diabetic patients in the forefoot, as skin breakdown exists more frequently in the forefoot compared to the rear foot during barefoot walking. Pataky et al. (14) also observed anterior displacement of weight-bearing during walking in diabetic patients compared with nondiabetic controls. Most of the plantar ulcers develop in the forefoot and toe regions (15). Zequera et al. (16) reported increased pressure in metatarsal heads and the second toe in a limited number of patients and added that every patient requires an individual assessment and often a personalized insole. In another study, the diabetic group had excessive peak plantar pressure with a longer time of exposure at each step under the big toe and fifth metatarsal head. The peak plantar pressure was found to be lower under the heel in the diabetic patients (14). In this present study, dynamic pedobarographic evaluation revealed significantly higher peak phalanx pressure in diabetic patients with disease duration more than 10 years when compared with patients having shorter disease duration, similar to the aforementioned studies. It has been found to be interesting by some authors that the plantar contact area gets narrowed as the disease gets longer, and consequently, the plantar pressure gets higher, parallel to the findings of this study. In fact, the sensor area of the forefoot is much higher than the area of the midfoot and hindfoot in pedobarographic measurements. In the diabetic foot, many studies have shown that the contact area gets lower and pressure gets higher with disease duration. Finally, this leads to the total contact area narrowing, in a dominant reason. In addition, neurological changes (sensorial, motor, and alternative gait patterns) may contribute to this evaluation, besides the biomechanical changes during the disease process.

Table 2. Comparison of static pedobarographic values between the groups

\begin{tabular}{|c|c|c|c|c|}
\hline & \multicolumn{2}{|c|}{$\begin{array}{c}\text { Disease duration more } \\
\text { than } 10 \text { years (Group } 1) \\
(n=43)\end{array}$} & \multicolumn{2}{|c|}{$\begin{array}{c}\text { Disease duration less } \\
\text { than } 10 \text { years (Group 2) } \\
(n=41)\end{array}$} \\
\hline & Right & Left & Right & Left \\
\hline Forefoot peak pressure $\left(\mathrm{N} / \mathrm{cm}^{2}\right)$ & $9.5(3.9)$ & $9.7(4.2)$ & $9.8(4.5)$ & $9.1(3.7)$ \\
\hline Rear foot peak pressure $\left(\mathrm{N} / \mathrm{cm}^{2}\right)$ & $11.6(4.9)$ & $11.6(5.4)$ & $12.2(4.3)$ & $11.4(3.3)$ \\
\hline Total plantar force $(\mathrm{N})$ & $411.4(144.6)$ & $352.1(115.6)$ & $456.4(132.9)$ & $425.0(137.6)$ \\
\hline Forefoot plantar force percentage (\%) & $46.1(9.0)$ & $48.8(11.3)^{*}$ & $44.4(12.1)$ & $44.8(10.0)^{*}$ \\
\hline Rear foot plantar force percentage (\%) & $53.9(9.0)$ & $51.2(11.3)^{\dagger}$ & $55.6(12.1)$ & $55.2(10.0)^{\dagger}$ \\
\hline Total contact area $\left(\mathrm{cm}^{2}\right)$ & $90.2(17.9)$ & $81.3(19.0)$ & $94.5(15.4)$ & $88.7(15.4)$ \\
\hline Forefoot plantar contact area percentage (\%) & $57.6(13.1)$ & $56.9(11.5)$ & $58.2(13.4)$ & $56.9(11.8)$ \\
\hline Rear foot plantar contact area percentage (\%) & $42.3(13.2)$ & $40.4(11.5)$ & $41.8(13.4)$ & $42.9(11.7)$ \\
\hline
\end{tabular}

Data presented are mean values (SD).

${ }^{*}: p<0.05$ (between the left forefoot plantar force percentage (\%))

${ }^{\dagger}: \mathrm{p}<0.05$ (between the left rear foot plantar force percentage (\%))

The unit of pressure was $\mathrm{N} / \mathrm{cm}^{2}$. 
Tuna et al.

Table 3. Comparison of dynamic pedobarographic values between the groups

\begin{tabular}{|c|c|c|c|c|}
\hline & $\begin{array}{l}\text { Disease } \\
\text { than } 10 y\end{array}$ & $\begin{array}{l}\text { n more } \\
\text { iroup 1) }\end{array}$ & $\begin{array}{r}\text { Disease } \\
\text { than } 10 y\end{array}$ & $\begin{array}{l}\text { ion less } \\
\text { Group 2) }\end{array}$ \\
\hline & Right & Left & Right & Left \\
\hline Peak phalanx pressure & $42.7(24.4)$ & $44.1(21.2)^{*}$ & $36.6(22.4)$ & $33.8(19.5)^{*}$ \\
\hline Medial forefoot peak pressure & $22.5(15.2)$ & $21.4(11.2)$ & $23.2(12.9)$ & $32.4(24.3)$ \\
\hline Middle forefoot peak pressure & $24.1(7.2)$ & $29.7(16.0)$ & $30.1(19.9)$ & $31.1(14.5)$ \\
\hline Lateral forefoot peak pressure & $21.0(9.3)$ & $22.5(6.9)$ & $26.3(19.2)$ & $24.4(9.3)$ \\
\hline Middle foot peak pressure & $12.4(6.6)$ & $12.6(5.8)$ & $17.5(15.2)$ & $12.7(5.8)$ \\
\hline Rear foot peak pressure & $20.6(7.8)$ & $20.6(8.0)$ & $20.7(8.1)$ & $21.2(5.9)$ \\
\hline Plantar contact area & $127.1(14.7)^{\dagger}$ & $127.6(18.3)$ & $134.1(14.2)^{\dagger}$ & $133.5(15.1)$ \\
\hline Maximum force & $47.7(21.6)$ & $49.4(20.4)$ & $49.2(22.5)$ & $48.0(22.4)$ \\
\hline
\end{tabular}

A small area exposed to a force always shows greater impact forces when compared to a larger area under the impact of the force with the same magnitude (17). Thereby, increased force and pressure on a decreased contact area may cause foot ulcers at the first metatarsal and hallux (18). In another study, contact plantar surface area in diabetic patients was found to be reduced compared to control subjects (14). As an expected resultant finding, we observed a significantly smaller contact area in the right feet of diabetic patients with disease duration more than 10 years. Consequently, the pressure increases might be attributable to this condition.

A previous study showed that the threshold pressure level for ulcer occurrence is $10 \mathrm{~kg} / \mathrm{cm}^{2}$ (19). None of the patients in this study had plantar pressure values over this this threshold value. Perhaps this may be due to the fact that we excluded patients with ulceration. However, this parameter is not the only one for ulcer occurrence. The presence of peripheral neuropathy and the long duration of foot-floor contact time are important, as well (14). The majority of past studies compared plantar pressure values between neuropathic and non-neuropathic feet. However, some studies have reported no significant differences between them $(20,21)$.

\section{Conclusion}

Our study confirmed the findings of previous studies in which a pressure shift to the forefoot in diabetic patients was reported. This study mainly concludes that the plantar pressure values get higher in diabetic patients with higher disease duration. For patients with foot ulceration, offloading is the main therapeutic strategy (12). These findings and further studies may contribute to approaches to "offload" or redistribute high pressure in the foot by individualized therapeutic sole production and shoe modifications.

Ethics Committee Approval: Ethics committee approval was received for this study from the Ethics Committee of Trakya
University Medical Faculty of Scientific Investigation and Evaluation. (Committee Date: 9.03.2011/no: 21)

Informed Consent: Written informed consent was obtained from patients who participated in this study.

Peer-review: Externally peer-reviewed.

Author Contributions: Concept - H.T.; Design - H.T., M.B., S.G.; Supervision - N.A.S., N.T.; Funding - H.T., M.B., S.G.; Materials - H.T., M.B., S.G., N.T.; Data Collection and/or Processing N.A.S, Ö.T., N.S.; Analysis and/or Interpretation - H.T., N.T., N.S., S.G.; Literature Review - H. T., N.A.S, Ö.T.; Writer - H.T., M.B., N.T.; Critical Review - H.T., M.B., N.T., S.G.

Conflict of Interest: No conflict of interest was declared by the authors.

Financial Disclosure: The authors declared that this study has received no financial support.

Etik Komite Onayı: Bu çalışma için etik komite onayı Trakya Üniversitesi Tıp Fakültesi Bilimsel Araştırma ve Değerlendirme Etik Kurul Raporu 9.03.2011 tarih 21 karar no ile alınmıştır.

Hasta Onamı: Yazılı hasta onamı bu çalışmaya katılan hastalardan alınmıştır.

Hakem değerlendirmesi: Dış bağımsız.

Yazar Katkıları: Fikir - H.T.; Tasarım - H.T., M.B., S.G.; Denetleme - N.A.S., N.T.; Kaynaklar - H.T., M.B., S.G.; Malzemeler - H.T., M.B., S.G., N.T.; Veri toplanması ve/veya işlemesi - N.A.S, Ö.T., N.S.; Analiz ve/veya yorum - H.T., N.T., N.S., S.G. ; Literatür taraması - H.T., N.A.S., Ö.T.; Yazıyı yazan - H.T., M.B., N.T.; Eleştirel İnceleme - H.T., M.B., N.T., S.G.

Çıkar Çatışması: Yazarlar çıkar çatışması bildirmemişlerdir. 
Finansal Destek: Yazarlar bu çalışma için finansal destek almadıklarını bildirmişlerdir.

\section{References}

1. Helfand AE. Assessing and preventing foot problems in older patients who have diabetes mellitus. Clin Podiatr Med Surg 2003;20:573-82. [CrossRef]

2. Bus SA. Foot structure and footwear prescription in diabetes mellitus. Diabetes Metab Res Rev 2008;24:90-5. [CrossRef]

3. Boulton AJ, Betts RP, Franks Cl, Ward JD, Duckworth T. The natural history of foot pressure abnormalities in neuropathic diabetic subjects. Diabetes Res 1987;5:73-7.

4. Pham H, Armstrong DG, Harvey C, Harkless LB, Giurini JM, Veves A. Screening techniques to identify people at high risk for diabetic foot ulceration: a prospective multicenter trial. Diabetes Care 2000;23:606-11. [CrossRef]

5. Pecoraro RE, Reiber GE, Burgess EM. Pathways to diabetic limb amputation. Basis for prevention. Diabetes Care 1990;13:513-21. [CrossRef]

6. Ahroni JH, Boyko EJ, Forsberg RC. Clinical correlates of plantar pressure among diabetic veterans. Diabetes Care 1999;22:965-72. [CrossRef]

7. Cavanagh PR, Bus SA. Off-loading the diabetic foot for ulcer prevention and healing. J Am Podiatr Med Assoc 2010;100:360-8. [CrossRef]

8. Operating Manuel Mini-Emed System, Novel, Munich, 1991.

9. Hennig EM, Staats A, Rosenbaum D. Plantar pressure distribution patterns of young school children in comparison to adults. Foot Ankle Int 1994;15:35-40. [CrossRef]

10. Moss SE, Klein R, Klein BE. The 14-year incidence of lower-extremity amputations in a diabetic population. The Wisconsin Epidemiologic Study of Diabetic Retinopathy. Diabetes Care 1999;22:951-9. [CrossRef]
11. Boulton AJ, Kirsner RS, Vileikyte L. Clinical practice. Neuropathic diabetic foot ulcers. N Engl J Med 2004;351:48-55. [CrossRef]

12. Boulton AJ. Pressure and the diabetic foot: clinical science and offloading techniques. Am J Surg 2004;187:17-24. [CrossRef]

13. Mueller MJ, Zou D, Bohnert KL, Tuttle LJ, Sinacore DR. Plantar stresses on the neuropathic foot during barefoot walking. Phys Ther 2008;88:1375-84. [CrossRef]

14. Pataky Z, Assal JP, Conne P, Vuagnat H, Golay A. Plantar pressure distribution in Type 2 diabetic patients without peripheral neuropathy and peripheral vascular disease. Diabet Med 2005;22:762-7. [CrossRef]

15. Prompers L, Huijberts M, Apelqvist J, Jude E, Piaggesi A, Bakker K, et al. High prevalence of ischaemia, infection and serious comorbidity in patients with diabetic foot disease in Europe. Baseline results from the Eurodiale study. Diabetologia 2007;50:18-25. [CrossRef]

16. Zequera ML, Solomonidis S. Performance of insole in reducing plantar pressure on diabetic patients in the early stages of the disease. Conf Proc IEEE Eng Med Biol Soc 2010;2010:2982-5.

17. van Schie $\mathrm{CH}$. A review of the biomechanics of the diabetic foot. Int J Low Extrem Wounds 2005;4:160-70. [CrossRef]

18. Hughes J, Clark P, Klenerman L. The importance of the toes in walking. J Bone Joint Surg Br 1990;72:245-51.

19. Boulton AJ, Betts RP, Franks Cl, Newrick PG, Ward JD, Duckworth T. Abnormalities of foot pressure in early diabetic neuropathy. Diabet Med 1987;4:225-8. [CrossRef]

20. D'Ambrogi E, Giurato L, D'Agostino MA, Giacomozzi C, Macellari V, Caselli A, et al. Contribution of plantar fascia to the increased forefoot pressures in diabetic patients. Diabetes Care 2003;26:1525-9. [CrossRef]

21. Giacomozzi C, Caselli A, Macellari V, Giurato L, Lardieri L, Uccioli L. Walking strategy in diabetic patients with peripheral neuropathy. Diabetes Care 2002;25:1451-7. [CrossRef] 